DOI: $10.17805 /$ zpu.2020.1.4

\title{
Роль самотворчества в становлении индивидуальности в Античности: духовное упражнение «научиться жить»
}

\author{
A. А. ГОРЕЛОВ \\ ИНСТИТУТ ФИЛОСОФИИ РОССИЙСКОЙ АКАДЕМИИ НАУК, \\ Т. А. ГОРЕЛОВА \\ МОСКОВСКИЙ ГУМАНИТАРНЫЙ УНИВЕРСИТЕТ
}

В статье анализируется значение самотворчества в культуре. Самотворчество определяется как особая разновидность творчества, относящегося к самому творцу, который пытается изменить себя в соответствии со своими представлениями об идеале. Самотворчество, как и творчество, самосознание, смыслополагание, формирование системы ценностей можно отнести к духовности, высшей способности человека. Поскольку дух призван выполнять миссию управления - мыслями, чувствами, поведением человека, должны существовать практики «тренировки» духа, «духовные упражнения».

Прослеживаются позиции различных философских школ Античности - Платона, Аристотеля, киников, эпикурейцев и стоиков - в ракурсе одного из четырех типов духовных упражнений, предложенных П. Адо, - упражнения «научиться жить». Античность создала несколько систем догматов как поле для рациональной созерцательности и систем философского самоконтроля, учитывающих разные возможности и наклонности людей, заложив, таким образом, основы самотворчества.

Ключевые слова: самотворчество; Античность; духовное упражнение; созерцательность; самоконтроль; платонизм; аристотелизм; кинизм; эпикурейство; стоицизм

\section{BВEАЕНИЕ}

$\mathrm{M}$ ы понимаем самотворчество (далее - СТ) как особую разновидность творчества, относящегося к самому творцу, который пытается изменить себя в соответствии со своими представлениями об идеале. Аля определения философского статуса понятия СТ было проведено его сравнение с близкими по смыслу понятиями «творчество», «самосовершенствование», «творчество жизни», «самоактуализация»и «практика себя» (Горелов, Горелова, 2019: Электронный ресурс).

Античность первой попыталась создать представление о творчестве как способ-

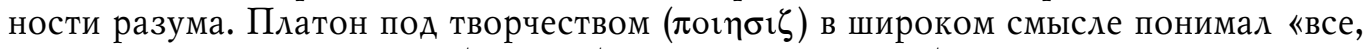
что вызывает переход из небытия в бытие... создание любых произведений искусства и ремесла» (Платон, 1993а: 115 (Пир, 205с)). В узком смысле творчество включает лишь «область музыки и стихотворных форм» (там же). Главной особенностью творчества является его цельность (Платон, 1990b: 375 (Ион, 532c)). Целостность не отрицает многоаспектности творчества: с одной стороны, существуют «два рода творчества: один - человеческий, другой - божественный» (Платон, 1993b: 341 (Софист, 265е), с другой стороны, возможны два произведения творчества - сама вещь и некий ее образ: «оно (творчество. - A. Г., T. Г.) с помощью строительного мастерства воздвигает дом, а с помощью живописи нечто другое, создаваемое подобно человеческому сну для бодрствующих» (там же: 342 (Софист, 266с)). Иными словами, «одно - это то, которое выполняется посредством орудий, в другом тот, кто творит призраки, сам делает себя орудием этого» (там же: 343 (Софист, 267а)). Поэты как те, кто создает призраков, «не мудростью могут они творить то, что творят, а какою-то прирожденной способностью и в исступлении, подобно гадателям и прорицателям» (Платон, 1990а: 75 (Апология Сократа, 22с)). Такое «немудрое» по- 
стижение мира дает не столько истину, но чаще ложь, потому что, «составив для людей лживые сказания, они (поэты. - $A . \Gamma$., T. Г.) стали им их рассказывать» (Платон, 1994а: 141 (Государство, 377d)). Платон фактически противопоставляет творчество как поэзию философии как любви-дружбе с мудростью, представляя, что «слово "мудрость" (бофı $\alpha)$ означает “захватить порыв" <...> Так вот имя София и означает захватывание ( $\varepsilon \pi \alpha \varphi \eta)$ такого порыва, поскольку все сущее как бы несется» (Платон, 1990е: 647 (Кратил, 412b)). Не исступление, а разум является гарантом возможности «схватывания» в результате познания. Противопоставляя философов поэтам и утверждая как бы непринадлежность философии сфере «пойезис», Платон подчеркивал ее особый путь не как творчества, а как достижения истинь, причем этот путь требует особой подготовки, самоизменения того, кто на него ступил. Платоновскую линию, устанавливающую принципиальное отличие философии как устремления к чистой мысли от других созидательных культурных форм, поддержала вся последующая античная философия.

Современное и античное понимания творчества разнятся. Творчество понимается в наше время как сложная многомерная духовная деятельность, в которой задействованы разные области сознания. Как любой акт деятельности, творчество структурируется в соответствии с поставленной целью, внутренним или внешним ее мотивом, средствами для достижения и ожидаемым результатом. Цель творчества вытекает из системного единства с другими сознательными процессами, в наибольшей степени из триединства «творчество - поиск истины - поиск смысла (идеала)». Средством осуществления являются особые способы и методы духовной деятельности. Спектр мотивов может быть чрезвычайно разнообразным, но его результатом всегда является новизна (наличие принципиально нового духовного продукта). Опознавательными сигналами творчества являются динамичность, парадоксальность, интуитивность, непредсказуемость, спонтанность.

К сходному выводу о творчестве приходит М. Хайдеггер на основе анализа понятия «техника». Следуя Платону о двойственном результате творчества - в виде вещи или образа, «техник» как инструментальная, «вещная» деятельность тоже несет в себе момент «пойезис». Согласно учению Аристотеля о причинах, у любой вещи, события или процесса существуют четыре причины: causa materialis, материал, то, из чего создается; causa formalis, форма, какую принимает этот материал; causa finalis, цель, которой определяются эти форма и материал; causa efficiens как результат. Что координирует эти причины? По Хайдеггеру, управление этими исходными поводами осуществляет мастерство, творческая способность деятеля. В этом случае техника выступает как вид раскрытия потаенности. «Такая “техник” относится к про-из-ведению, к “пойезис"; она есть нечто “поэтическое” < ...> Сущность техники расположена в области, где имеют место открытие и его непотаенность, где сбывается истина» (Хайдеггер, 1993: 225). Таким образом, техника в широком смысле - как создание единичной вещи или способ управления процессом (в соответствии с замыслом и мастерством человека) есть способ раскрытия потаенности. Напрашивается аналогия для творчества в целом, в соответствии с которой новизна может (иди должна?) присутствовать на всех четырех уровнях причин: на материальном как новое поле осознания (или ракурс), на формальном как новая методология, на финальном как новая цель, на уровне результата как новизна продукта. В свете этого анализа и сама философия предстает не сферой чистой мысли, а творческим постижением реальности. 
Возвращаясь к цели нашего исследования и имея в виду проведенный анализ внутренней структуры творчества на основе его причин, отметим, что в работе над собой, в СТ можно обнаружить те же четыре направления: материалом, над которым надо трудиться, становятся тело и душа идущего, форма, в которую они облекаются, определяется целью и ожидаемым результатом, но главным, пятым элементом творчества, является «мастерство», «техника» работы над собой, преображающая человека, чтобы он стал «сосудом» для принятия истины. Именно в этом смысле «техника себя» становится составной частью философского «пойезиса». Так, не особенно сознавая СТ, античные философы смогли определить его структуру, которая включает преобразование тела и души, оформление способов этого преобразования, постановку цели и совершенствование «техники себя». Если творчество в широком смысле осуществляет «выведение из потаенности» (там же: 225), то философское творчество, требуя «осуществления истины», с необходимостью несет в себе элементы СТ: преображая себя, человек одновременно является и материалом, и инструментом, и мастером, и творческим «произведением».

Внешняя структура творчества как триединство «творчество - поиск истины поиск смысла» в Античности имела гораздо более открытый и явный характер: возникшая новая отрасль духовной культуры - философия - главным смыслом своего творчества назвала поиск истины. Аля этого поиска нужен особый человек способный к свободному творчеству, т. е. такой, который может себя к нему подготовить через автотрансформацию (СТ). Именно поэтому философия способствовала созданию широкого спектра духовных «техник себя» в рамках различных философских школ. Причем эти техники проходят три исторические стадии: самую общую, имеющую отношение к разным классам и разным периодам Античности, «заботы о себе», история которой охватывает «тысячу лет с V в. до Р. Х. по V в. после, которая вела от первых форм философской деятельности, какими мы их видим у греков, к первым формам христианской аскетики» (Фуко, 2007: 24). Как продвижение «заботы о себе» возникли более интеллектуальные и оформленные «практики себя», к которым обращались в той или иной мере все философские школы после Сократа, и «культура себя», включившая стоические и неоплатонические практики как вершину данного пути в эллинистическую эпоху (I-II вв.). Хотя античная философия не работала с понятием «дух», именно Античность осознала присутствие некой системы (идея, Аогос и т. А.), которая призвана выполнять миссию управления - мыслями, чувствами, поведением человека и попыталась проявить ее в виде практики «тренировки» духа, создав первоначальные формы духовных техник (с явным упором на СТ), которые позже применялись также в христианстве и исламе.

В данной работе мы проследим позиции различных философских систем (школ) Античности в отношении возможности самоизменения человека, имея в виду один из типов духовных упражнений - «научиться жить».

\section{АУХОВНЫЕ УПРАЖНЕНИЯ}

КАК УНИВЕРСААЬНАЯ ОСНОВА СТ В АНТИЧНОСТИ

Главной особенностью античной философии можно считать отсутствие дистанции между теорией и практикой: людей, не стремящихся согласовать свою жизнь с излагаемыми ими взглядами, в Аревней Греции называли софистами, а не философами. Философы же изначально считали своим призванием не только познание мира, но и изменение человека. Поэтому все известные философские системы того 
времени уделяли внимание методологии воздействия на человека, которые можно назвать «духовными упражнениями».

«Эти упражнения... соответствуют преобразованию видения мира и метаморфозе личности. Слово “духовный” действительно позволяет понять, что эти упражнения являются творчеством не только мысли, но всей психики индивида... благодаря им индивид возвышается к жизни объективного Ауха» (Адо, 2005: 22). П. Адо называет четыре главных типа духовных упражнений: 1) «научиться жить»; 2) «научиться вести диалог»; 3) «научиться чтению»; 4) «научиться умирать». П. Адо находит очень точное определение этим духовным техникам - «научение», поскольку они «шли от головы» и преподавались в философских школах. Но в этом «научении» присутствует момент, который характеризует именно духовную практику - стремление к разрыву с повседневным образом жизни, пренебрежение общепринятым жизнеустройством, привычными взглядами и поведением. Философские школы Античности объединяли людей духовно свободных и признававших друг друга как близких по духу. Именно поэтому большинство этих школ просуществовало в течение нескольких веков.

Античная установка «научиться жить» в широком смысле предполагает преуспеяние «в искусстве жизни, в конкретной установке, в сообразном стиле жизни, затрагивающем все существование» (там же: 23-24). Она означает переход от неподлинного состояния жизни, которое подчиняется внутреннему голосу страстей и страхов и разъедается внешними обстоятельствами забот, бедности и т. П., к подлинной жизни, основанной на сознании и внутренней свободе. Беспорядочные страсти и необоснованные страхи, суета заботы - главные помехи на пути саморазвития. Задача философии состоит в создании такой экзистенциальной методологии, которая действовала бы по принципу самолечения, врачевания души без посторонней помощи. Каждая философская система Античности по существу и занималась созданием философской «медицины» души, способствуя смене видения и бытия человека. Главная проблема, которая возникает в этом случае: как выявить то благо, которое человек в состоянии добыть, и как отличить то зло, которого можно избежать.

Вторую - «научиться вести диалог» и третью - «научиться чтению» группы духовных упражнений, по классификации Адо, мы объединяем в одну группу «научиться общению с Аругим», имея в виду, что диалог - это непосредственное общение, а чтение - это опосредованное, через текст, общение с той же целью найти истину. Еще одна группа духовных упражнений «научиться умирать» предлагает при выборе между Жизнью и Идеей выбрать последнее. Это сознательная процедура освобождения от телесных тягот и страстей ради обретения независимости мышления, его перехода к универсальности и объективности. Ауховным упражнениям «научиться общению с Аругим» и «научиться умирать» будет посвящена следующая наша работа.

Изначальный мотив философа, который собственно и является само-творчеством, - создать свое рачиональное представление о состоянии совершенства и соответствующие духовные практики, упражнения разума, настраивающие индивидуальную жизнь на духовное продвижение к идеалу мудрости, к божественному проявлению в себе как субъекте некоего Всеобщего. Ауховные практики, которые при этом создавались, были СТ их авторов, но поскольку у каждого из них находилось много последователей, эти упражнения несли в себе ядро всеобщего, как бы общий план 
структуры и возможностей СТ в рамках философии. Три указанных выше типа духовных упражнений были ядром философских систем Античности начиная от Сократа, Платона, Аристотеля и их последователей, а позже систем Эпикура, киников, стоиков и неоплатоников. Вклад каждого из философских направлений в реализацию определенного типа духовных упражнений и соответственно в СТ различен и определяется центральной идеей концепции.

\section{«НАУЧИТЬСЯ ЖИТЬ» КАК МЕТОАОАОГИЯ УХОАА ОТ ПОВСЕАНЕВНОСТИ: СОКРАТ И КИНИКИ}

Группа духовных упражнений «научиться жить» является базовой для всех философских систем Античности: они для этого и были задуманы. Но степени реализации этой установки в жизни ее создателя весьма различны.

Первой и самой яркой фигурой гениального творчества собственной жизни является Сократ. Его облик не отвечает требованиям правильности, некоей середины, которые, казалось бы, должны соответствовать греческому пониманию гармонии: напротив, он парадоксален, противоречив, т. е. не гармоничен. Во-первых, бросается в глаза парадокс телесности: Сократ внешне был уродлив (рачьи глаза, губастый рот, брюшко, см.: Адо, 2005: 90) и в описании Платона из «Пира» напоминал сатира Марсия, мифологического демона, наполовину животное, наполовину человека (Платон, 1993a: 126 (Пир, 215 b - c)), но был харизматически притягателен для афинского юношества (за что и был позже казнен). Второй парадокс можно назвать психологическим: будучи открытым для диалога с любым гражданином Афин, он оказался совершенно «замаскированным» для истории, так как не оставил ни одной строки, а в своих устных дискуссиях под маской иронии подчас представал в прямо противоположных позициях по отношению к разным собеседникам. Магия сократического диалога заключалась в том, что одних он «жалил», как овод, а у других как бы брал на себя их сомнение и растерянность, укрепляя веру ведомого в его собственный разум, и приводил того к лично переживаемой истине. В этом смысле можно говорить о Сократе как врачевателе (кстати, свой духовный метод он назвал майевтикой по аналогии с родовспоможением, т. е. вполне медицинским термином). Третий парадокс, парадокс духовного плана, заключается в том, что общегреческой мудрости «познай самого себя» он как бы противопоставляет «я знаю, что ничего не знаю» (Аиоген, 1986: 103). Но на самом деле творческий уровень прожитой жизни оказался так высок, что история отметила его как первого создателя концепции и методологии самопознания и, добавим, СТ. Сократ умер не только за конкретную идею, но за идею как таковую, и с его идей-понятий начинается философия. Наградой его жизни стала не только похвала от пифии: «Сократ превыше всех своею мудростью» (там же: 104), но не меркнущая благодарность человечества.

Целостность жизни Сократа можно обосновать наличием двух верований - верой в существование истины как таковой и верой в то, что в лабиринте каждого индивидуального сознания до нее можно добраться и узреть неискаженной. Жизнь Сократа предстает как вершина СТ, как уверенно пройденный путь на границе идеальной возможности и человеческой реальности, который С. Кьеркегор назвал «серьезностью существования» (цит. по: Адо, 2005: 103). В сократовской трактовке человек как бы «оседлывает» фатум своей жизни, чтобы поводьями подправлять направление движения. Идеальная модель существования, реализованная Сократом, уравновешивала и гармонизировала основные ценности античной культуры - муд- 
рость, добродетель, удовольствие и справедливость при доминировании мудрости. Позже концептуальная формула Сократа «Мудрость $=$ Аобродетель $=$ Удовольствие = Справедливость» расщепилась на две колеи - практики (как у самого Сократа) у киников (Антисфен, Аиоген Синопский и др.) и киренаиков (Аристипп из Кирены и его ученики) и теории с привкусом практики у Платона (Академия) и Аристотеля (перипатетики). Взрывное разнообразие философских систем последователей Сократа говорит о том, что он стал образцом самореализации и родоначальником особой методологии СТ, о которой вспоминала не только Античность, но и Новое время и которая применима сейчас.

Итак, основные положения Сократа, важные для СТ, заключаются в следующем: 1) существует истина как соответствие знания объективной реальности, по которой человек создает самого себя; 2) существует доказательное знание, с помощью которого достигается истина (причем Сократа интересует прежде всего объективное знание о самом человеке в соответствии с главенством в Античности принципа «познай самого себя»).

Киники, признав необходимость лишь первой части формулы Сократа «Мудрость = Аобродетель», поставили на первое место не теорию, а практику и пошли на разрыв с общественными условностями, предпочитая простую «собачью» жизнь и эпатаж как метод воздействия на окружающих.

Киник Аиоген избрал свой образ жизни, «когда поглядел на пробегавшую мышь, которая не нуждалась в подстилке, не пугалась темноты и не искала никаких мнимых наслаждений» (Аиоген, 1986: 221). Переход к простоте и труд как мерило ценности жизни человека у киников становятся точкой отсчета потенциала самоизменения. Кинизм не мог быть теорией: согласно Аиогену, глубина истины определяется практически - тем, сколько насмешки она способна выдержать. На вопрос, что дала ему философия, Аиоген ответил: «По крайней мере готовность ко всякому повороту судьбы» (там же: 233). Он не оставил трактатов, потому что жить для него было важнее, чем записывать. Но, несмотря на это, образ дерзкого киника в анекдотах сохранился гораздо лучше, чем сохранились бы его записи. Оттенки кинизма как духовного движения присутствуют в практиках мировых религий - в христианском юродстве, дзен-буддизме, суфизме. Он стал формой «ответа воли к жизни на то, что ей причинили теории и идеологии: отчасти духовное искусство выживания, отчасти интеллектуальное Сопротивление...» (Слотердайк, 2009: 441). Кинизм привнес в мировую культуру «изначальную связь между счастьем, нетребовательностью и интеллектом - мотив, который обнаруживается во всех движениях, выступающих за vita simplex (простую жизнь - A. Г., Т. Г.)» (там же: 253).

Противоположностью простоте является парадоксальность кинизма: осознавая себя личностью, обладающей внутренней свободой духа, киник призывает человека стать «собакой», т. е. животным, не способным к сознанию и внутренней свободе. Аругой стороной парадоксальности является попытка самоосознавания и самоизменения через провокативное столкновение с повседневностью и общественными устоями. Например, Аиоген с его жестокими выходками, грубостью и аморальным поведением в роли «врачевателя общества» понимается неоднозначно: как прописавший этому «пациенту» (обществу) лекарство или яд, потому что не каждый его соотечественник мог воспринять провокацию как дорогу к осознанию. Еще одним парадоксом античного кинизма является тот факт, что социальный тип, призывающий жить «природной» жизнью, смог выкристаллизоваться и обрести отчетли- 
вую форму только в городской цивилизации - под прессом общественного мнения и всеобщей любви-ненависти к себе. Практически соединяя простоту и парадоксальность, киники уловили диалектику СТ, которая требует и того, и другого.

Понимая физиологическую природу многих телесных удовольствий - от еды, сна, тепла и т. А., киники выстраивают некую пирамиду удовольствий, когда более низкая, телесная, форма наслаждения оставляется ради более высокой, духовной, формы. Этого не приняли киренаики, которые, напротив, в соответствии с предпочтением второй части формулы «Мудрость $=$ Удовольствие» считали, что надо стремиться к телесным удовольствиям, и призывали укреплять свои позиции в обществе и наслаждаться простыми радостями жизни (чем фактически порывали с особой философской стезей).

Если позицию киренаиков следует признать преимущественно примитивно-обывательской, над которой лишь слегка приподнимается классификация удовольствий, данная Аристиппом, то аскетическая позиция киников, направленная явно на чрезвычайные усилия по творчеству собственной жизни, вполне вписывается в философское направление «научиться жить». Заслуга киников, и прежде всего наиболее прославленного из них Аиогена Синопского, заключается в том, что они признали жизненную практику не менее, чем теорию, важной для самосовершенствования личности. Единство теории и практики - важнейшее положение СТ.

\section{РАЦИОНАИЬНАЯ СОЗЕРЦАТЕАЬНОСТЬ КАК АУХОВНОЕ УПРАЖНЕНИЕ: ШКОАЫ ПААТОНА И АРИСТОТЕАЯ}

Настоящую революцию в философии совершил Платон. Он не только отказался от «уличной» философии, но «порвал с досократической космологией в поисках внутренней гармонии Вселенной и ввел в обиход метафизический идеализм» (Жижек, 2018: 101). С. Жижек называет философию Платона «ошеломляющей встречей с Идеей» (там же: 103). Отныне теоретическое знание (догматы) призваны стать не выученным знанием, а «природой и жизнью», и именно такое знание становится основой любой практической философии.

Платон «отбрасывает длинную тень» на все последующие философские системы, создатели которых вынуждены соглашаться или не соглашаться с ним. Так, под впечатлением Платона постепенно возникают фундаментальные догматы и следующие из них правила жизни платонизма, аристотелизма, эпикуреизма, стоицизма и позже неоплатонизма, которые были внутренне целостными каждая по-своему и потому не претерпели в Античности особых изменений. Это были конструктивные сферы творчества, которые принимали новобранцев и давали им шанс на СТ, но сами их конструкции не могли быть поколеблены в силу их сферичности. Имея в виду образ сферы, можно предположить, что правильность формы (поведение человека) регулировалась в результате философского "самолечения», самоконтроля, практики себя (М. Фуко), а масштабы, т. е. диаметр сферы, - в результате способности к рашиональному созерианию. Способы регуляции, или «упражнения», касались всех областей жизнедеятельности. Упражнения были двоякого типа - на ограничение и на развитие. Упражнения по ограничению для тела - ограничение в еде, питье, похоти и т. п., по развитию - гимнастика. Упражнения по ограничению души (желаний и страстей) - гнева, страха, любопытства, болтливости, зависти, жадности и т. п., по развитию - самообладание (enkrateia), опирающееся на волю. Все философские системы единодушны не только в наборе ненужных вожделений, но 
и в том, что необходимо воспитывать в себе способность различать между зависящими от человека и не зависящими от него обстоятельствами. Это дело трудное, утешительно лишь то, что общая гармоничность Универсума ведет к тому, что и в отношении человека «богатство, требуемое природой, ограниченно и легко достижимо» (Аиоген, 1986: 408).

Соотношение этих упражнений в философских системах в некотором смысле отражает престиж философии как отрасли культуры в данную эпоху: взлету сопутствует преобладание упражнений рационального созерцания в системах Сократа, Платона, Аристотеля, упадку - упражнения самоконтроля в системах киников, Эпикура, стоиков. Философское творчество первых предполагает наличие более или менее благоприятной социальной среды, вторыми социум воспринимается как среда недоброжелательная, но и в тех, и других природа остается основным предметом созерцания.

Упражнения разума - философская созерцательность - для античных философов не имеют ограничений, но могут быть развивающими только в том случае, если разуму задано верное направление - поиск божественной истины. «Как разбегаются страхи души, расступаются стены / Мира, - и вижу я ход вещей в бесконечном пространстве.../ Все это некий восторг поселяет в меня и священный / Ужас, когда сознаю, что силой твоею открылась / Вся природа везде и доступной сделалась мысли» (Аукреций, 1983: 93, 94 (III, 16, 30)). Но и упражнения разума имеют некоторое сходство с упражнениями для тела и души: они требуют повторения и ритмичности, т. е. таких же тренировок, как упражнения для тела, и таких же процедур, как врачебные. Ауховные упражнения в широком смысле включают в себя все указанные способы регуляции тела, души и разума на основе ограничения и развития, но центром их являются упражнения разума, базис которых составляют теоретические системы, догматы.

Фундаментальные установки созерцательности меняются: это воспоминание у платоников, логика у перипатетиков, безмятежность (ataraxia) у эпикурейцев, бдительность (prosoche) у стоиков. Аля Платона и Аристотеля базовым элементом рационального созерцания было состояние мышления в процессе создания догматов: из него рождался образ жизни, доставляющий максимальное удовольствие, приводящий к божественному благу и развивающий творческий потенциал человека. «Мудрецы-платоники и аристотелики... через свою жизнь мыслителей возвышаются до уровня Божественной мысли» (Адо, 2005: 244). Огромность рациональных перспектив их философских систем (у каждого по-своему) стимулировала созерцательные размышления, увлекательные «упражнения разума», для огромного количества последователей (Академия и перипатетики). Но философская практика в них «уходила с улиц». «Он (Платон. - $A . \Gamma$. $T . \Gamma$.) отказался от сократовской иронии и обычая бродить по базару и мастерским, охотиться за молодыми людьми и заводить с ними беседы. Отказался он также от важной надменности пифагорейцев, от их вечно запертых дверей и от их довода “сам сказал” - со всеми он был общителен и доброжелателен» (Олимпиодор, 1986: 415).

Значение учения Платона для СТ многопланово. Во-первых, Платон осуществил глубокий и всесторонний синтез древнегреческой философии: помимо Гераклита и Сократа, он использовал представление Аемокрита об атомах-идеях, учение Пифагора о числах; учение Анаксагора о гомеомериях как образах вещей. Этим он предоставил широкое догматическое поле для личного выбора. Во-вторых, выделив 
чувственный и умопостигаемый миры, он выстроил иерархию, в которой умопостигаемый (надземный и неизменный) мир идей становился большей реальностью, чем переменчивый чувственный мир: «..должно разграничить вот какие две вещи: что есть вечное, не имеющее возникновения бытие и что есть вечно возникающее, но никогда не сущее» (Платон, 1994b: 432; курсивы источника. - А. Г., Т. Г. (Тимей, 27d)). Мир идей становится объективной основой общечеловеческих ценностей, которые одновременно и идеалы (с высшей идеей - идеей блага), и вектор, задающий направление саморазвития и творчества человека. В-третьих, механизмом постижения мира идей, по Платону, является воспоминание через «возвышенную любовь» к нему (agape), а не «дружба» (philia) (как первоначально признавали философы), что задает совсем другую тональность СТ: оно поднималось от телеснодушевных упражнений к духовному созерцанию «мира идей», при этом «врачебный» потенциал системы увеличивался в силу расширения сознания. Но сам Платон творческий потенциал философствования отрицал: философ ищет то, что есть, он не придумывает нового, т. е. не творит. Поэтому самую творческую, в современном понимании, часть интеллектуалов - поэтов - он не допустил в свое идеальное государство. В-четвертых, душа обладает особыми свойствами: она «самодвижется и состоит их трех частей: разумная часть ее имеет седалище в голове, страстная часть - в сердце, а вожделительная - при пупе и печени» (Аиоген, 1986: 148). В соответствии с преобладающей частью души возможны три типа людей: правители (для Платона лучшие из них философы), воины, ремесленники и земледельцы. Трем частям их душ присуща своя из трех добродетелей: мудрость, мужество и умеренность. Тройственной структурой души Платон одновременно объясняет и различные источники ее «самодвижения» (в отличие от Пифагора, который считал, что к «самодвижению» способны лишь те, кто приходят в мир «смотреть»), и идеальное государственное устройство. Гармонию всех трех устанавливает четвертая, всеобщая, добродетель из мира идей - справедливость. Наибольшее благо в душе человека и в мире - это единство и гармония, а наибольшее зло - раздор. Исходя из его концепции, целью СТ становится поиск гармонии.

Самоконтроль, по Платону, заключается в ориентации души на созерцание мира идей, к проясняющемуся в процессе размышления взгляду на реальные вещи, которые являются лишь «тенями» их идеальных прообразов. Иными словами, самоконтроль в философской системе Платона совпадает с созерцательностью. Но «лечебное» значение самоконтроля остается и у него: в несчастье не следует, подобно ребенку, ушибившись, реветь, хватаясь за ушибленное место, «мы должны приучать душу как можно скорее обращаться к врачеванию и возмещать потерянное и больное, заглушая лечением скорбный плач» (Платон, 1994а: 401 (Государство, 604d)).

Понятие идеи, которое Платон положил в основу своей философии, представляет собой не просто конкретное выражение чего-либо, как это обычно понимается, а скорее духовный идеал, которого должен достигать человек. Значение этого конструкта для СТ очевидно. Аля того чтобы преобразовывать себя, надо знать, каким ты хочешь и каким объективно должен быть. Особо важна вера в объективный характер идеала.

Иную основу рациональной созерцательности и СТ видит Аристотель. Он идет от теоретического знания, хотя его понимание теории отличается от современного: во-первых, потому, что созерцательная способность человека является результатом его духовных упражнений, во-вторых, теория - это настоящие активные мысли, 
«цель которых - в самих себе и которые существуют ради самих себя» (Аристотель, 1984c: 595 (Политика, VII, III, 1325 b21)). Более того, «деятельность ума как созерцательная... помимо себя самой не ставит никаких целей... она и будет полным счастьем человека... ибо при счастье не бывает ничего неполного» (Аристотель, 1984a: 282-283 (Никомахова этика, 1177 b20, 26)). Созерцательная жизнь понимается как назначение человека. Целью рационального созерцания становится не воспоминание, как у Платона, а познание, основанное на законах разума - логике, и систематизация наиболее общего, что есть в вещах, - первых причин их существования.

Различая мудрость и разумность, Аристотель пишет, что «мудрость направлена на вещи доказуемые и неизменные, разумность же - не на них, а на вещи изменчивые» (Аристотель, 1984b: 334 (Большая этика, 1197 а35)), т. е. мудрость как высшая форма разумности и способность постигать сущность вещей является атрибутом лишь философского познания. Разум же, выступающий в роли управителя у мудрости, отвечает за науку, искусство, практичность, изобретательность. По Аристотелю, «наука есть приобретенная способность душ к доказательствам <...> человек знает тогда, когда он уверен и ему ясны принципы [знания] <...> искусство и приобретенное душевное свойство творчества, следуюшего истинному разуму, - одно и то же» (Этика Аристотеля, 1908: 110) (курсив автора - А. Г., Т. Г.). Искусство отличается от науки тем, что «принцип создаваемого заключается в творящем лице» (там же), а не в природе или в необходимости. Определяя науку как «способность к доказательствам» и не считая ее (как и философию) личным творчеством, важно, что он утверждает искусство как «душевное свойство творчества» способным следовать «истинному разуму», т. е. способность к творчеству и разумность, по Аристотелю, внутренне связаны.

Аристотель осознает еще одну важную сторону творчества - cnособность $\kappa$ деятельности, активность. Заботясь о своих душевных качествах, человек создает себя. Отсюда, его назначение - в разумной деятельности, т. е. в такой, когда каждое действие сообразуется со специально относящейся к нему добродетелью. Аобродетельно и само приобретение данного свойства. Цель разумной деятельности - «деятельность души, сообразная с добродетелью, а если добродетелей несколько, то в деятельности, сообразной с лучшею и совершеннейшею добродетелью», и притом в течение всей жизни, «ибо “одна ласточка еще не делает весны”, как не делает ее один день» (там же: 12). Так, осознание цели и важность планомерной деятельности по образованию и закреплению привычек становится отправной точкой СТ.

Из двух других частей души - растительной и животной, только вторая не является врожденной, а приобретается воспитанием и сознательно выбранными привычками, поэтому она требует уравновешивания - этических добродетелей. По природе люди склонны к крайностям. Одна из крайностей всегда более ошибочна, чем другая. Поэтому из двух зол надо выбирать меньшее (отважность лучше трусости, бесстрастность лучше невоздержанности) (Аристотель, 1984а: 92 (Никомахова этика, 1109 а15-20)). Но наилучшей, по Аристотелю, оказывается «золотая середина»:

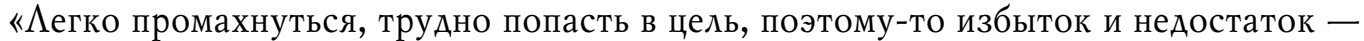
принадлежности порока, середина - принадлежность добродетели» (Этика Аристотеля, 1908: 31). Правило «золотой середины» относится и к телесным проявлениям, если они во власти человека: «Усиленное или недостаточное занятие гимнастикой губит телесную силу, точно так же и недостаточная или излишняя пища и питье 
губит здоровье» (там же: 25). Поскольку наслаждение и страдание управляют всеми действиями человека, главная цель самоконтроля - научиться жестко управлять собой: «Мы будем нуждаться в законах... охватывающих всю жизнь» (Аристотель, 1984а: 288 (Никомахова этика, 1180 а3)).

С позиции Аристотеля методология СТ требует создания таких жизненных привычек, которые соответствуют внутреннему поиску «середины» как закону, имеющему объективные общечеловеческие критерии. Формулируя правило «золотой середины», он действует как настоящий ученый, который отбрасывает крайние величины как нерепрезентативные и ищет средние для оформления закона. «В итоге человеческое существование всецело регламентировано сетью законов» (Хоружий, 2010: 15). Но СТ не имеет формы закона: человек Аристотеля удобен для общества, но не годится для творчества, которое требует «выхода за рамки» - обыденности, общества, эпохи и даже субъектности.

Предназначение свободы воли человека заключается в том, под какие жернова закона себя подставить - под те, которые поднимут вверх, или под те, которые сбросят: «...если прекрасная и постыдная деятельность в нашей власти, а равно и воздержание, и если добродетель и порочность именно в этом и заключается, то, значит, в нашей власти быть нравственными или порочными людьми» (Этика Аристотеля, 1908: 47). По Аристотелю, не знание является источником добродетели, в чем были уверены Сократ и Платон: нравственный человек может быть невеждой, а знающий - безнравственным, а нравственно-волевое устремление к «золотой середине», которая отражает природный закон. Таким образом, Аристотель отделяет деятельность разума - созерцательность, которой он посвящает «Метафизику», от душевной деятельности по изменению себя, основания которой изложены в «Этике». Последняя, будучи наукой практической, существует не затем, чтобы знать, что такое добродетель, а чтобы стать добродетельным. Таково же различие между мечтой о возможности изменить себя и реальным СТ.

Необходимость формирования привычек и следование принципу «золотой середины» - главный вклад Аристотеля в теорию и практику СТ.

\section{САМОКОНТРОАЬ КАК АУХОВНОЕ УПРАЖНЕНИЕ: ШКОАА ЭПИКУРА И СТОИКИ}

Если СТ с позиции философских систем Сократа, Платона и Аристотеля можно считать «творчеством созерцательности», то практическая философия Эпикура несет в себе множество моментов «творчества самоконтроля». Эпикур не стремился, как его предшественники - Сократ, киники, Платон, активно воздействовать на окружающих, и это связано как с внешними факторами - упадком общественной жизни и философии в его время, так и с его собственным состоянием - с молодых лет он страдал тяжелейшим и неизлечимым недугом, причинявшим ему ужасные страдания (может быть, поэтому избегание страданий он считал высшим благом). И хотя он основал свою школу - «Сад Эпикура», та напоминала скорее замкнутую пифагорейскую общину, а не платоновскую академию, что не помешало ей оставить след в практиках самоизменения.

Созерцательная часть философии Эпикура была не оригинальной - материализм-атомизм. Но за миром однородных атомов наблюдает не холодный ученый, а человекобог: «Что касается эпикурейского мудреца, как и боги, он видит, как рождается на основе атомов в бесконечной пустоте бесконечность миров... и ничто никогда не задевает покой его души» (Адо, 2005: 245). Эпикур оставался материалис- 
том и в отношении человека, считая, что принцип удовольствия заложен в основу человеческой психической жизни, поэтому от удовольствия нельзя отказаться: остается лишь следовать ему. Важнейшее понятие античной философии «добродетель», по Эпикуру, нужна лишь в том случае, если приносит человеку удовольствие и делает его счастливым. «Красоту, добродетель и тому подобное следует ценить, если они доставляют удовольствие; если же не доставляют, то надо с ними распрощаться» (Материалисты ... , 1955: 226). Если Аристотель шел от идеализма Платона к реальному человеку, рассматривая добродетели как свойства чувства и разума, то материалист Эпикур пошел еще дальше: он поставил чувство выше разума, подчинив последний телу: «Начало и корень всякого блага - это удовольствие чрева <...> Не считай нисколько не согласным с учением о природе [т. е. неестественным] то, что когда кричит плоть, кричит душа» (Антология ..., 1969: 360). Но все же в соответствии с общегреческим представлением о гармонии и Космосе он считал, что «чистого наслаждения нельзя получить без изучения природы» (Аиоген, 1986: 408), т. е. оно находится в гармонии с созерцательностью.

Эпикур задумал одну из самых рациональных в Античности систем самоконтроля, создав классификацию удовольствий (наслаждений) и разделив их на динамические и статические: «Наслаждения в покое - это безмятежность и безболезненность, наслаждения в движении - радость и удовольствие» (Аиоген, 1986: 406). Статические наслаждения он считал предпочтительными, поскольку динамические всегда сопровождаются предшествующим желанием, приносящим страдания, а статические - нет, и поэтому последние создают некое состояние равновесия без страдания. В дополнение к классификации удовольствий он разрабатывает свою концепцию желаний, разделив их на естественные и вздорные, а естественные - на необходимые (пища, жилище) и не необходимые (изысканные яства и т. п.).

Рационализировав самоконтроль, он создал простое и понятное основание для СТ: «Не следует насиловать природу, следует повиноваться ей, а мы будем повиноваться ей, необходимые желания исполняя, а также естественные, если они не вредят, а вредные сурово подавляя» (Материалисты ..., 1955: 220). Аля Эпикура самоконтролем является поддержание баланса удовольствия и страдания. Чтобы делать всегда правильный выбор - в пользу удовольствия, превышающего страдания, необходимы мудрость и благоразумие: « чтобы насладиться большими удовольствиями; полезно воздержаться... от некоторых удовольствий, чтобы не терпеть более тяжких страданий» (там же: 233). Мудрость избавляет от ложных страхов и ложного понимания удовольствия. Благоразумие учит, что «нельзя жить сладко, не живя разумно, нравственно и справедливо, и, наоборот, нельзя жить разумно, нравственно и справедливо, не живя сладко» (Аиоген, 1986: 407).

Первое практическое житейское правило для сохранения состояния удовольствия - умеренное пользование дарами жизни, предпочтение духовных удовольствий чувственным. Эпикур считал «худшей душевную боль, потому что тело мучится лишь бурями настоящего, а душа - и прошлого, и настоящего, и будущего. Точно так же и наслаждения душевные больше, чем телесные» (там же: 406). Аля него философское врачевание заключается в повороте души от повседневных житейских забот к радости существования. Через устранение телесных страданий и душевных тревог человек приходит к здоровью тела и безмятежности души, что является целью счастливой жизни. 
Казалось бы, какое отношение к творчеству имеет базовый лозунг системы Эпикура: «Живи незаметно»? Ведь каждый творец хочет представить результаты творчества и быть положительно оцененным социумом. Все дело в том, что любая философская практика призывала к внутреннему самосозиданию, для которого не важны и невозможны внешние оценки. В этом смысле вся философия Античности это скрытое и нарочито скрываемое от окружающих СТ. Именно поэтому античные философы порывают с обычаями и привычками простых смертных. Аюбовь к надобыденной мудрости делает философа чуждым миру. Точно так же результатом СТ во все времена может быть неблагожелательность окружающих, социальное отторжение, состояние «белой вороны».

Наряду с классификацией желаний, разделенных Эпикуром на те, которые следует или можно исполнять, и те, от исполнения которых следует отказаться, в заслугу ему ставят и освобождение человека от напрасных страхов - страха богов, явлений природы и социальных изменений, мешающих двигаться на пути СТ. В этом идеи Эпикура перекликались с идеями стоиков, которые в других отношениях были ему альтернативными.

Пришедшая на смену эпикурейской безмятежности как идеалу жесткая система самоконтроля стоиков обращается именно к внутреннему миру человека, что позволило ей дойти до нас в наиболее неизмененном виде. Созерцательность философии стоиков, с одной стороны, синтезирует предшествующую рациональность греков и подводит итог античной философии, но с другой - как бы входит составной частью в систему духовных упражнений, чего не было в предшествующих философских системах. Ааже в образе философии как фруктового сада, где логика является оградой, физика - деревьями, а этика - плодами, отражен акцент именно на человека. Стоическая картина мира - это циклический процесс, который начинается с огня, который порождает Космос, природу, человека, и заканчивается «космическим пожаром». Поскольку в мире все предопределено, лучше, если воля человека согласуется с объективным природным законом, который соответствует стремлению к добродетели: она реализует назначение человека и ведет к счастливой жизни.

Система самоконтроля стоицизма поэтому направлена на понимание того, какое действие согласно с природой, т. е. надлежаще, а какое нет. Надлежащие поступки - чтить родителей, братьев, отечество, любить друзей. Наивысшее благо - добродетель. Аля стоика душа не обладает бессмертным статусом: человек живет здесь и сейчас, и эту единственную жизнь он и должен построить. Вопреки Аристотелю они считали, что истинное назначение разума состоит не в том, чтобы искать «золотую середину», а в освобождении от страстей (которых четыре - желание, страх, наслаждение, скорбь), поскольку они - неразумные и несогласные с природой движения души. О приближении каждого индивидуального разума к универсальному природному закону свидетельствуют два проявления - «апатия», идеальное состояние души, неподверженной страстям, и «автаркия», самостоятельность, независимость от чужого и умение доводьствоваться своим.

Как и киники, стоики отрицали значение наслаждения, но главным для них была не жизнь по типу природной, а жизнь, отданная выполнению долга, как его понимал разум: надо не убегать от мира, а принимать его таким, каков он есть, быть покорным судьбе. Покорность стоиков основана на гордости и возвышении «Я» над суетящимся муравейником повседневности, поскольку над ними не было личного бога, как позже у христиан, а лишь безличное дыхание. Гордость провозглашала отсутст- 
вие жалости и сострадания как к самому себе, так и к другому. Если киники демонстрировали стойкость по отношению к природным условиям жизни, то стоики делали то же самое по отношению к социальным условиям: «Изменить... порядок вещей мы не в силах, - зато в силах обрести величие духа, достойное мужа добра, и стойко переносить все превратности случая, не споря с природой» (Сенека, 1977: 270). Ищи опору в собственной душе, которая и есть бог в человеке, советует Сенека. Он не «взвешивает» удовольствие и страдание, как Эпикур, для него смерть - способ освобождения. Больше, чем любая другая философская система, стоицизм становится духовным упражнением «научения умирать».

Равенство перед смертью и фортуной делает людей равноправными и в жизни. «Они рабы? Нет, люди. Они рабы? Нет, твои соседи по дому. Они рабы? Нет, твои смиренные друзья. Они рабы? Нет, твои товарищи по рабству, если ты вспомнишь, что и над тобой, и над ними одинакова власть фортуны» (там же: 77). Но это «товарищество» по рабству освобождает человека, хотя бы потенциально: «Рабство не проникает в человека в целом - лучшая часть его изъята из рабства. Только тело его подневольно и принадлежит господину, но душа его принадлежит самой себе <...>. Тело является тем, что по воле судьбы отдано во власть господина, он его покупает и продает; внутренняя же сущность не может быть отдана в рабство» (там же). Правоту и объективность этой стоической установки на равноправие подтверждает история: из трех самых известных римских стоиков один (Сенека) был придворным, другой (Эпиктет) - рабом, а третий (Марк Аврелий) - императором.

Наиболее яркую систему духовных упражнений стоицизма создал Эпиктет, открывший свою школу в Никополисе и хорошо осознававший преемственность философии: «Эпиктет лучше Сократа не будет. Но если не хуже, этого мне достаточно» (Беседы Эпиктета, 1997: 14). Первое, что требовалось ученику, - осознать собственную слабость и бессилие как душевную болезнь. Стоики считали, что философия есть лекарство для души, но чтобы человек захотел принять лекарство, он должен понять, что болен. Первый этап лечения - отбрасывание ложного знания, отказ от привычных представлений и подготовка чувства и воли к новому знанию. Реализация общей установки стоиков - стать добродетельным - требовала, по Эпиктету, теоретических знаний, внутреннего самоусовершенствования и практических упражнений («нравственной гимнастики»). На втором этапе реализовывались Ава основных принципа Эпиктета - «вьљерживай и воздерживайся»: стойко выдерживай все внешние трудности и ко всему относись спокойно; воздерживайся от любых проявлений собственных страстей, памятуя, что твои - только разум и душа как нечто единое, а не тело. Таким образом, стоики (как и неоплатоники), объединив духовные упражнения в систему и осознав ступенчатость пути, подошли к тому, что можно назвать духовной практикой, позже реализованной христианством.

Глубочайший социальный пессимизм римского стоика последнего периода Марка Аврелия - подводит стоицизм к некоему пределу, выражающему «мужество отчаяния»: «Теперь обратись к нравам окружающих - самого утонченного едва можно вынести; что себя самого еле выносишь, я уж не говорю. И вот в этой тьме, мути и потоке естества, и времени, и движения, и того, что движется, есть ли, не придумаю, хоть что-нибудь, что можно ценить, о чем хлопотать. Напротив, утешать себя нужно ожиданием естественного распада и не клясть здешнее пребывание, а искать отдохновение, единственно вот в чем: во-первых, ничего не случится со мной иначе, как в согласии с природой челого; во-вторых, дано мне не делать ничего про- 
тив моего бога и гения, потому что никто не заставит пойти против него» (Марк Аврелий, 1985: 25-26 (V, 10), курсив наш. - А. Г., Т. Г.). Отсюда утрата веры в возможность философского «врачевания»: «врачом» становится судьба, а зло мира горьким лекарством, которым нас лечит природа (там же: 25 (V, 8)). И принять нужно «с нежностью все то, что с тобой случается» (там же), потому что зло, как любое препятствие, помогает нам: «И продвигает в деле самая помеха делу и ведет по пути трудность пути» (там же: $27(\mathrm{~V}, 20))$. Боль же и наслаждение не имеют к СТ никакого отношения, так как они не делают человека ни лучше, ни хуже и поэтому не могут быть ни благом, ни злом.

Уровень достигнутого тестируется требованием одинакового ответа на любые внешние обстоятельства, что созвучно у Сенеки: «Поверь мне, великое дело играть всегда одну роль. Но никто, кроме мудреца, этого не делает; все прочие многолики» (Сенека, 1977: 310), и у Марка Аврелия: «Быть похожим на утес, о который неустанно бьется волна; он стоит, и разгоряченная влага затихает вокруг него» (Марк Аврелий, 1985: 22 (IV, 49)). Общая стоическая установка разумной необходимости подчинения всеобеему высшему началу объединяла трех выдающихся римских стоиков, различие их мировоззрения в том, что, по Сенеке, во внешнем мире все подчинено судьбе; по Эпиктету — воле богов; по Марку Аврелию - мировому разуму.

Стоическая система СТ требует непрерывной бдительности ума, энергии воли, напряжения души для того, чтобы родилась способность различать между зависящими от человека и не зависящими от него обстоятельствами. Эпикурейская система, напротив, считает безмятежность, освобождение от забот жизни и простую радость существования целью философского выбора. Но и в том, и в другом случае от «новобранца» требуется бдительное, постоянное и активное выполнение простых и фундаментальных правил, которые «всегда перед глазами»: «При каждом событии иметь перед глазами тех, с кем случалось то же самое, а потом они сетовали, удивлялись, негодовали. А теперь где они?» (Марк Аврелий, 1985: 41 (VII, 58)). Стоики добавили к тем видам страстей, от которых следует избавляться, по Эпикуру, страха и вздорных желаний, еще два вида - наслаждения и скорби, тем самым продолжая идти по пути освобождения от препятствий, мешающих человеку самосовершенствоваться. Сходство между стоиками и эпикурейцами заключалось в ориентации на жизнь по природе, замкнутость и автаркию, безмятежность и апатию, в представлении о материальности богов и души, смертности человека и его возвращении в мировое целое.

\section{ЗАКАЮЧЕНИЕ}

Таким образом, Античность создала несколько систем самосовершенствования, идущих от идеализма у Платона, реализма у Аристотеля, материализма у Эпикура, фатализма у стоиков. Каркас каждой из систем достаточно жесток, но внутренняя творческая пластичность позволяла новому последователю вносить свои идеи в магистральную догму. Точно так же системы философского самоконтроля учитывали индивидуальные возможности и наклонности, предлагая разные рецепты «врачевания»: воспоминание (платоники), логика (перипатетики), безмятежность (эпикурейцы), бдительность (стоики), но в конечном счете и доктрину, и лекарство для души человек выбирает себе сам. Таким образом, несмотря на разногласия философских школ, Античность создает многомерную и целостную модель СТ, все компоненты 
которой внутренне взаимосвязаны, и как бы задает его структуру на все времена уровень созерцательности, обращенный ввысь, и уровень самоконтроля, обращенный к глубинам человеческого Я.

Античная программа СТ содержит в себе ядро, которое в наше время было названо «глубинной экологией» (Батищев, 2015: 505-538). Глубинный уровень упражнения «научиться жить» предполагает мироутверждение как «предпочтение не себя Универсуму, но Универсума - себе» (там же: 534). Подлинная жизнь заключается в том, «чтобы вновь и вновь быть» (там же), т. е. соответствовать объективным процессам Универсума, быть уместным и сопричастным им в смысле универсальной взаимной «со-причастности каждого всем субъектам в Универсуме и всех — каждому» (там же: 535$)$.

В общей установке мироутверждения, казалось бы, присутствует момент отказа от самоутверждения, т. е. от СТ. На самом деле (и это хорошо ощущали древнегреческие философы), напротив, именно соответствие творческой свежести индивидуальной души и духа объективным космическим процессам давали ей шанс на «встречу с Универсумом». Аиалектика миро- и самоутверждения такова, что последнее без первого оборачивается отрицанием подлинного Я. Отрешившись от страхов и тягот обыденной жизни, человек может переживать «глубинное общение»: с одной стороны, как мироутверждение - выход в результате созерцательного акта за пределы индивидуальности, «со-причастие» Универсуму, а с другой - сотворение с помощью системы самоконтроля здорового внутреннего мира. Как провозглашает Античность, «искусство жить» управляется познавательной способностью сознания, которое через мгновения творчества открывает человеку природу, космос и самого себя.

\section{СПИСОК АИТЕРАТУРЫ}

Адо, П. (2005) Ауховные упражнения и античная философия / пер. с франц. при участии В. А. Воробьева. М. ; СПб. : ИзА-во «Степной ветер»; ИА «Коло». 448 с.

Антология мировой философии : в 4 т. (1969)/ ред. кол. В. В. Соколов и др. Философия древности и средневековья. М. : Мысль. Т. І. Ч. 1.576 с.

Аристотель (1984а) Никомахова этика // Аристотель. Сочинения : в 4 т. / ред. А. И. Аоватура. М. : Мысль. Т. 4.830 с. С. 53-294.

Аристотель (1984b) Большая этика // Аристотель. Сочинения : в 4 т. / ред. А. И. Аоватура. М. : Мысль. Т. 4.830 с. С. 295-374.

Аристотель (1984c) Политика // Аристотель. Сочинения : в 4 т. / ред. А. И. Аоватура. М. : Мысль. Т. 4.830 с. С. 375-644.

Батищев, Г. С. (2015) Особенности культуры глубинного общения // Батищев, Г. С. Избранные произведения / под общ. ред. 3. К. Шаукеновой. Алматы : Институт философии, политологии и религиоведения КН МОН РК. 880 с. С. 505-538.

Беседы Эпиктета (1997) / подг. Г. А. Таронян. М. : Аадомир. 412 с.

Горелов, А. А., Горелова, Т. А. (2019) Самотворчество как протестный потенциал духовной культуры [Электронный ресурс]// Научные труды Московского гуманитарного университета. № 1. C. 148-170. URL: http://journals.mosgu.ru/trudy/article/view/943 (дата обращения: 06.06.2019). DOI: $10.17805 /$ trudy.2019.1.14

Аиоген Ааэртский (1986) О жизни, учениях и изречениях знаменитых философов / ред. и авт. вступ. ст. А. Ф. Аосев, пер. М. А. Гаспарова. М. : Мысль. 571 с.

Жижек, С. (2018) Философское путешествие по концепту / пер. с англ. А. Я. Хамис. М. : РИПО $А$ классик. 240 с.

[Аукреций] Тит Аукреций Кар (1983) О природе вещей / пер. с лат. Ф. А. Петровского. М. : Художественная литература. 383 с. 
Марк Аврелий (1985) Размышления / пер. А. К. Гаврилова. А. : Наука. 246 с.

Материалисты Аревней Греции (1955)/ ред. и вступ. статья М. А. Аынник. М. : Гос. изА-во политической литературы. 239 с.

Олимпиодор (1986) Жизнь Платона // Аиоген Ааэртский. О жизни, учениях и изречениях знаменитых философов. Приложение / ред. и авт. вступ. ст. А. Ф. Аосев; пер. М. А. Гаспарова. М. : Мысль. 571 с. С. 412-415.

Платон (1990а) Апология Сократа // Платон. Собрание сочинений : в 4 т. / общ. ред. А. Ф. Аосева, В. Ф. Асмуса, А. А. Тахо-Годи ; примеч. А. Ф. Аосева и А. А. Тахо-Годи. М. : Мысль. Т. 1.860 с. С. 70-96.

Платон (1990b) Ион // Платон. Собрание сочинений : в 4 т. / общ. ред. А. Ф. Аосева, В. Ф. Асмуса, А. А. Тахо-Годи ; примеч. А. Ф. Аосева и А. А. Тахо-Годи. М. : Мысль. Т. 1.860 с. C. 372-385.

Платон (1990е) Кратил // Платон. Собрание сочинений : в 4 т. / общ. ред. А. Ф. Аосева, В. Ф. Асмуса, А. А. Тахо-Годи ; примеч. А. Ф. Аосева и А. А. Тахо-Годи. М. : Мысль. Т. 1.860 с. C. 613-681.

Платон (1993а) Пир // Платон. Собрание сочинений : в 4 т. / общ. ред. А. Ф. Аосева, В. Ф. Асмуса, А. А. Тахо-Годи ; примеч. А. Ф. Аосева и А. А. Тахо-Годи. М. : Мысль. Т. 2.528 с. C. 81-134.

Платон (1993b) Софист // Платон. Собрание сочинений : в 4 т. / общ. ред. А. Ф. Аосева, В. Ф. Асмуса, А. А. Тахо-Годи ; примеч. А. Ф. Аосева и А. А. Тахо-Годи. М. : Мысль. Т. 2.528 с. C. $275-345$.

Платон (1994а) Государство // Платон. Собрание сочинений : в 4 т. / общ. ред. А. Ф. Аосева, В. Ф. Асмуса, А. А. Тахо-Годи ; примеч. А. Ф. Аосева и А. А. Тахо-Годи. М. : Мысль. Т. 3. 654 c. C. $79-420$.

Платон (1994b) Тимей // Платон. Собрание сочинений : в 4 т. / общ. ред. А. Ф. Аосева, В. Ф. Асмуса, А. А. Тахо-Годи ; примеч. А. Ф. Аосева и А. А. Тахо-Годи. М. : Мысль, 1994. Т. 3. 654 c. C. $421-500$.

Сенека, А. А. (1977) Нравственные письма к Ауцилию. М. : Наука. 384 с.

Слотердайк, П. (2009) Критика цинического разума / пер. с нем. А. П. Перцева. Екатеринбург : У-Фактория ; М. : АСТ. 800 с.

Фуко, М. (2007) Герменевтика субъекта: Курс, прочитанный в Коллеж де Франс в 1981-1982 учебном году / пер. с фр. А. Г. Погоняйло. СПб. : Наука. 677 с.

Хайдеггер, М. (1993) Вопрос о технике // Хайдеггер, М. Время и бытие: Статьи и выступления / пер. с нем. В. В. Бибихина. М. : Республика. 447 с. С. 221-238.

Хоружий, С. С. (2010) Фонарь Аиогена. Критическая ретроспектива европейской антропологии. М. : Институт философии, теологии и истории св. Фомы. 688 с.

Этика Аристотеля (1908) / пер. Э. Радлова. СПб. : Филос. общество при Имп. СПб. ун-те. 207 с.

Аата поступления: 24.10.2019 г.

THE ROLE OF SELF-CREATION IN THE FORMATION OF INDIVIDUALITY IN ANTIQUITY: SPIRITUAL EXERCISE "LEARNING TO LIVE"

\section{A. A. GORELOV \\ RAS INSTITUTE OF PHILOSOPHY \\ T. A. GORELOVA \\ MOSCOW UNIVERSITY FOR THE HUMANITIES}

This article analyses the importance of self-creation in culture. Self-creation is defined as a special kind of creativity relating to the creator themself, who tries to change themself in accordance with their ideas about the ideal. Self-creation, as well as creativity, self-consciousness, conceptualization, the formation of a system of values can be attributed to spirituality, the higher ability of a person. Since the spirit is called upon to fulfill the mission of control over thoughts, feelings, human behavior, there should exist practices of "training" of the spirit, "spiritual exercises". 
The article traces the viewpoints of various philosophical schools of antiquity - Platonism, Aristotelianism, Cynicism, Epicureanism, and Stoicism - in the perspective of one of the four types of spiritual exercises proposed by P. Ado - the exercise "learn to live". Antiquity created several systems of dogmas as a field for rational contemplation and systems of philosophical self-control, taking into account different abilities and inclinations of people, thus laying the foundations of self-creation.

Keywords: self-creation; antiquity; spiritual exercise; contemplation; self-control; Platonism; Aristotelianism; Cynicism; Epicureanism; Stoicism

\section{REFERENCES}

Ado, P. (2005) Dukbovnye uprazhneniia $i$ antichnaia filosofiia / per. s frants. pri uchastii V. A. Vorob'eva. Moscow, St/ Petersburg, Izd-vo «Stepnoi veter»; ID «Kolo». 448 p. (In Russ.).

Antologiia mirovoi filosofii : in 4 vol. (1969) / editorial board: V. V. Sokolov et al. Moscow, Mysl'. Vol. I. Part 1. Filosofiia drevnosti i srednevekov'ia. 576 p. (In Russ.).

Aristotel' (1984a) Nikomakhova etika. In: Aristotel'. Sochineniia : in 4 vol./ red. A. I. Dovatura. Moscow, Mysl'. T. 4. 830 s. S. 53-294. (In Russ.).

Aristotel' (1984b) Bol'shaia etika. In: Aristotel'. Socbineniia : in 4 vol. / ed. by A. I. Dovatura. Moscow, Mysl'. Vol. 4. 830 p. Pp. 295-374. (In Russ.).

Aristotel' (1984c) Politika. In: Aristotel'. Socbineniia : in 4 vol. / ed. by A. I. Dovatura. Moscow, Mysl'. Vol. 4. 830 p. Pp. 375-644. (In Russ.).

Batishchev, G. S. (2015) Osobennosti kul'tury glubinnogo obshcheniia. In: Batishchev, G. S. Izbrannye proizvedeniia / ed. by Z. K. Shaukenova. Almaty, Institut filosofii, politologii i religiovedeniia KN MON RK. 880 p. Pp. 505-538. (In Russ.).

Besedy Epikteta (1997) / comp. by G. A. Taronian. Moscow, Ladomir. 412 p. (In Russ.).

Gorelov, A. A. and Gorelova, T. A. (2019) Samotvorchestvo kak protestnyi potentsial dukhovnoi kul'tury. Nauchnye trudy Moskovskogo gumanitarnogo universiteta, no. 1, pp. 148-170 [online] Available at: http://journals.mosgu.ru/trudy/article/view/943 (access date: 06.06.2019). (In Russ.). DOI: $10.17805 /$ trudy.2019.1.14

Diogen Laertskii (1986) O zbizni, ucheniiakh i izrecheniiakb znamenitykh filosofov / ed. by A. F. Losev, transl. by M. L. Gasparova. Moscow, Mysl'. 571 p. (In Russ.).

Zhizhek, S. (2018) Filosofskoe puteshestvie po kontseptu / transl. fron Engl. by D. Ia. Khamis. Moscow, RIPOL klassik. 240 p. (In Russ.).

[Lukretsii] Tit Lukretsii Kar (1983) O prirode vesbchei / transl. from Latin by F. A. Petrovskogo. Moscow, Khudozhestvennaia literatura. 383 p. (In Russ.).

Mark Avrelii (1985) Razmysbleniia / transl. by A. K. Gavrilova. Leningrad, Nauka. 246 p. (In Russ.).

Materialisty Drevnei Gretsii (1955)/ ed. by M. A. Dynnik. Moscow, Gos. izd-vo politicheskoi literatury. 239 p. (In Russ.).

Olimpiodor (1986) Zhizn' Platona. In: Diogen Laertskii. O zhizni, ucheniiakb i izrecheniiakb znamenitykb filosofov. Prilozhenie/ ed. by A. F. Losev ; transl. by M. L. Gasparova. Moscow, Mysl'. 571 p. Pp. 412-415. (In Russ.).

Platon (1990a) Apologiia Sokrata. In: Platon. Sobranie socbinenii : in 4 vol. / ed. by A. F. Losev, V. F. Asmus and A. A. Takho-Godi. Moscow, Mysl'. T. 1.860 p. Pp. 70-96. (In Russ.).

Platon (1990b) Ion. In: Platon. Sobranie socbinenii : in 4 vol. / ed. by A. F. Losev, V. F. Asmus and A. A. Takho-Godi. Moscow, Mysl'. Vol. 1.860 p. Pp. 372-385. (In Russ.).

Platon (1990e) Kratil. In: Platon. Sobranie socbinenii : in 4 vol. / ed. by A. F. Losev, V. F. Asmus and A. A. Takho-Godi. Moscow, Mysl'. Vol. 1.860 p. Pp. 613-681. (In Russ.).

Platon (1993a) Pir. In: Platon. Sobranie socbinenii : in 4 vol./ ed. by A. F. Losev, V. F. Asmus and A. A. Takho-Godi. Moscow, Mysl'. Vol. 2. 528 p. Pp. 81-134. (In Russ.).

Platon (1993b) Sofist. In: Platon. Sobranie socbinenii : in 4 vol. / ed. by A. F. Losev, V. F. Asmus and A. A. Takho-Godi. Moscow, Mysl'. Vol. 2. 528 p. Pp. 275-345. (In Russ.).

Platon (1994a) Gosudarstvo. In: Platon. Sobranie socbinenii : in 4 vol. / ed. by A. F. Losev, V. F. Asmus and A. A. Takho-Godi. Moscow, Mysl'. Vol. 3. 654 p. Pp. 79-420. (In Russ.). 
Platon (1994b) Timei. In: Platon. Sobranie socbinenii : in 4 vol. / ed. by A. F. Losev, V. F. Asmus and A. A. Takho-Godi. Moscow, Mysl'. Vol. 3. 654 p. Pp. 421-500. (In Russ.).

Seneka, L. A. (1977) Nravstvennye pis'ma k Lutsiliiu. Moscow, Nauka. 384 p. (In Russ.).

Sloterdaik, P. (2009) Kritika tsinicheskogo razuma / transl. from Germ. by A. P. Pertsev. Ekaterinburg, U-Faktoriia ; Moscow, AST. 800 p. (In Russ.).

Fuko, M. (2007) Germenevtika sub »ekta: Kurs, prochitannyi v Kollezb de Fransv 1981-1982 uchebnom godu / transl. form Fr. by A. G. Pogoniailo. St. Petersburg, Nauka. 677 p. (In Russ.).

Khaidegger, M. (1993) Vopros o tekhnike. In: Khaidegger, M. Vremia i bytie: Stat'i i vystupleniia / transl. from germ. by V. V. Bibikhin. Moscow, Respublika. 447 p. Pp. 221-238. (In Russ.).

Khoruzhii, S. S. (2010) Fonar' Diogena. Kriticheskaia retrospektiva evropeiskoi antropologii. Moscow, Institut filosofii, teologii i istorii sv. Fomy. 688 p. (In Russ.).

Etika Aristotelia (1908) / transl. by E. Radlov. St. Petersburg, Filos. obshchestvo pri Imp. SPb. un-te. 207 p. (In Russ.).

Submission date: 24.10.2019.

Горелов Анатолий Алексеевич - доктор философских наук, ведущий научный сотрудник Института философии РАН. Адрес: 119842, Россия, г. Москва, ул. Гончарная, д. 12. Тел.: +7 (495) 697-91-28. Эл. алpec: evolepis@iph.ras.ru

Горелова Татьяна Анатольевна - доктор философских наук, профессор кафедры философии, культурологии и политологии Московского гуманитарного университета. Адрес: 111395, Россия, г. Москва, ул. Юности, д. 5. Тел.: +7 (499) 374-55-11. Эл. адpec: fylosofy@mosgu.ru

Gorelov Anatoliy Alekseyevich, Doctor of Philosophy, Leading Research Fellow, RAS Institute of Philosophy. Postal address: 12, Goncharnaya St., Moscow, Russian Federation, 119842. Tel.: +7 (495)697-91-28. E-mail: evolepis@iph.ras.ru

Gorelova Tatyana Anatolyevna, Doctor of Philosophy, Professor, Department of Philosophy, Culturology and Politology, Moscow University for the Humanities. Postal address: 5, Yunosti St., Moscow, Russian Federation, 111395. Tel.: +7 (499) 374-55-11. E-mail: fylosofy@mosgu.ru 